\title{
Potential Mutations Associated With Occult Hepatitis B Virus Status
}

\author{
Sima Besharat ${ }^{1,2}$; Aezam Katoonizadeh ${ }^{1}$; Abdolvahab Moradi ${ }^{2, *}$ \\ ${ }^{1}$ Liver and Pancreatobiliary Diseases Research Center, Digestive Disease Research Institute, Tehran University of Medical Sciences, Tehran, IR Iran \\ ${ }^{2}$ Golestan Research Center of Gastroentrology and Hepatology, Golestan University of Medical Sciences, Gorgan, IR Iran \\ ${ }^{*}$ Corresponding Author: Abdolvahab Moradi, Golestan Research Center of Gastroentrology and Hepatology, Golestan University of Medical Sciences, Gorgan, IR Iran. Tel: +98- \\ 1712340835; +98-9111772107, Fax: +98-1712369210, E-mail: abmoradi@yahoo.com
}

Received: October 6, 2013; Revised: January 14, 2014; Accepted: February 20, 2014

\begin{abstract}
Context: Occult hepatitis B virus (HBV) status (OHBS) is simply defined as the presence of HBV DNA in the liver (with or without detectable HBV DNA in the serum), in the absence of serum HBV surface antigen (HBsAg). Importance of OHBS is mostly clinical, related to its possible role in spreading through blood transfusion and liver transplantation; causing classic forms of HBV. Mechanisms underlying this entity are poorly defined. Several possibilities have been suggested, with major classification into two groups: defective host immune response and viral replication activity through mutations of HBV DNA sequence. Mutations are extensively investigated in all four overlapping open reading frames (ORFs) of HBV genome, to define their possible role in the pathogenesis of OHBS. Some of these mutations like S-escape mutants could not be detected by the routine available assays, making them difficult to diagnosis. Therefore, trying to detect this covert condition could be more helpful for defining better preventive and therapeutic strategies.

Evidence Acquisition: In the present study we provided an in-depth review of the most important new data available on different mutations in HBV genome of patients with OHBS, which may play a role in the pathogenesis of OHBS. The data were collected through reviewing the full-text articles, identified by the PubMed search, using the following keywords and their different combinations: occult hepatitis B, HBV genome, "a" determinant, HBV open reading frames, S mutations, X mutations, P mutations and C mutations.

Results: Variants within the major hydrophilic region (MHR) of the HBsAg, deletions in the pre-S1region, codon stop in the Sopen reading frames (ORF), sporadic non common mutations, some mutations affecting the posttranslational production of HBV proteins in the $S$ ORF like deletion mutations, mutations in start codon and nucleotide changes in the X ORF, deletion and point mutations in P ORF and sometimes, nucleotide substitution in the C ORF are among the assumed mutations detected to have a role in OHBS appearance.

Conclusions: Studies mostly lacked a control group and the whole-length HBV sequencing was scant with conflicting results, suggesting that OHBS is often a result of multiple mechanisms. Additional studies on full-length HBV genomes from occult and non-occult HBV cases may shed more light on the interplay between different mechanisms involved in the pathogenesis of OHBS.
\end{abstract}

Keywords: Hepatitis B; Mutation; Virus Diseases

\section{Context}

Hepatitis B virus (HBV) infection is a global health problem, affecting more than 2 billion people worldwide, of whom approximately 350 million suffer from HBVinduced chronic liver diseases $(1,2)$. Depending on the interactions between the host and the virus, the natural course of HBV infection can be highly heterogeneous (3). Chronic HBV infection is diagnosed by detection of serum hepatitis B surface antigen (HBsAg), however, sometimes HBV infection can be presented in the absence of serum HBsAg, which is known as occult HBV status (OHBS). Accordingly, OHBS is characterized by the presence of HBV DNA in the liver, in the absence of serum HBsAg, with or without detectable HBV DNA in the serum. On the basis of HBV antibody profile, OHBS may be distinguished as: seropositive-OHBS (anti-HBc and/or anti-HBs positive) and Seronegative-OHBS (anti-HBc and anti-HBs negative) (4). The clinical relevance of OHBS has not been investigated extensively; however, several studies have suggested a potential association between OHBS and increased risk of cirrhosis and hepatocellular carcinoma (HCC). In addition, it can be transmitted throughliver transplantation or blood transfusion $(2,5,6)$.

During HBV replication, HBV DNA transcription occurs via a reverse transcriptase enzyme, which performs both priming and elongation activities. Viral reverse transcriptase lack of proof-reading ability, leads to the emergence of different mutations $(5,7)$. The seronegativity in patients with OHBS may be due to mutations happening through different mechanisms, including changing the immunoreactivity of different viral proteins and the serum level of HBsAg (7).

\subsection{Virus Description}

$\mathrm{HBV}$ is a small enveloped virus, containing partially double-stranded DNA. The HBV DNA genes are transcribed 
in four different open reading frames (ORFs). There are four partially overlapping ORFs encoding seven different HBV proteins. The largest ORF is the POL ORF, which encodes polymerase proteins. The S ORF comprises the pre-S1, pre-S2 and $S$ regions and codes for large, middle and small sized inter-membrane surface proteins. The $C$ ORF consists of pre core and core regions and codes the capsid (core) and the hepatitis B e antigen (HBeAg) proteins. HBeAg seems to have a role in the regulation of the immune response. The last ORF is $\mathrm{X}$, which encodes the $\mathrm{X}$ protein. The transcription regulation activity of this protein has been suggested by some investigators (Figure 1) (5, 8-14).

Mechanisms underlying OHBS are poorly understood. Several possibilities have been suggested including: A) interference of HBV replication by other viruses (like HCV in case of HCV coinfection), B) integration of HBV-DNA into host cell chromosomes, C) formation of circulating HBV-containing immune complexes, which are not detected by routine HBsAg determining tests, D) altered host immune responses leading to the maintenance of HBV infection in a latent state until transmission to another individual occurs (mostly in case of immunosuppressive therapy), E) different mutations in HBV DNA sequence which is the main focus of the current review and will be discussed in detail (Table 1) $(2,6,15)$.

\section{Evidence Acquisition}

In the present study we provided an in-depth review of the most important new data available on different mutations in HBV genome of patients with OHBS, which may play a role in the pathogenesis of OHBS. The data were collected through the review of the full-text articles identified by PubMed search, using the following keywords 2and their different combinations: occult hepatitis $B$, HBV genome, "a" determinant, HBV open reading frames, $\mathrm{S}$ mutations, $\mathrm{X}$ mutations, $\mathrm{P}$ mutations and $\mathrm{C}$ mutations.

\section{Results}

\subsection{Mutations in the S Region of $H B V$ and Occult HBV Status}

The $S$ region of ORFs consists of three AUG codons coding the expression of three proteins: large (L), middle (M) and small (S). Pre-S1 domain is unique for L protein. Pre-S2 domain is the shared sequence with the M protein and the $S$ domain is seen in all three proteins. The $L$ and S proteins are essential for virion formation and the $\mathrm{M}$ could enhance the virion secretion efficiency $(19,34,35)$. The $S$ and $M$ proteins are detected as HBsAg. HBsAg is a peptide with 226 amino acids (aa) with a single major antigenic determinant called the "a" determinant, located in the

HBV genome (3.2 K.B)

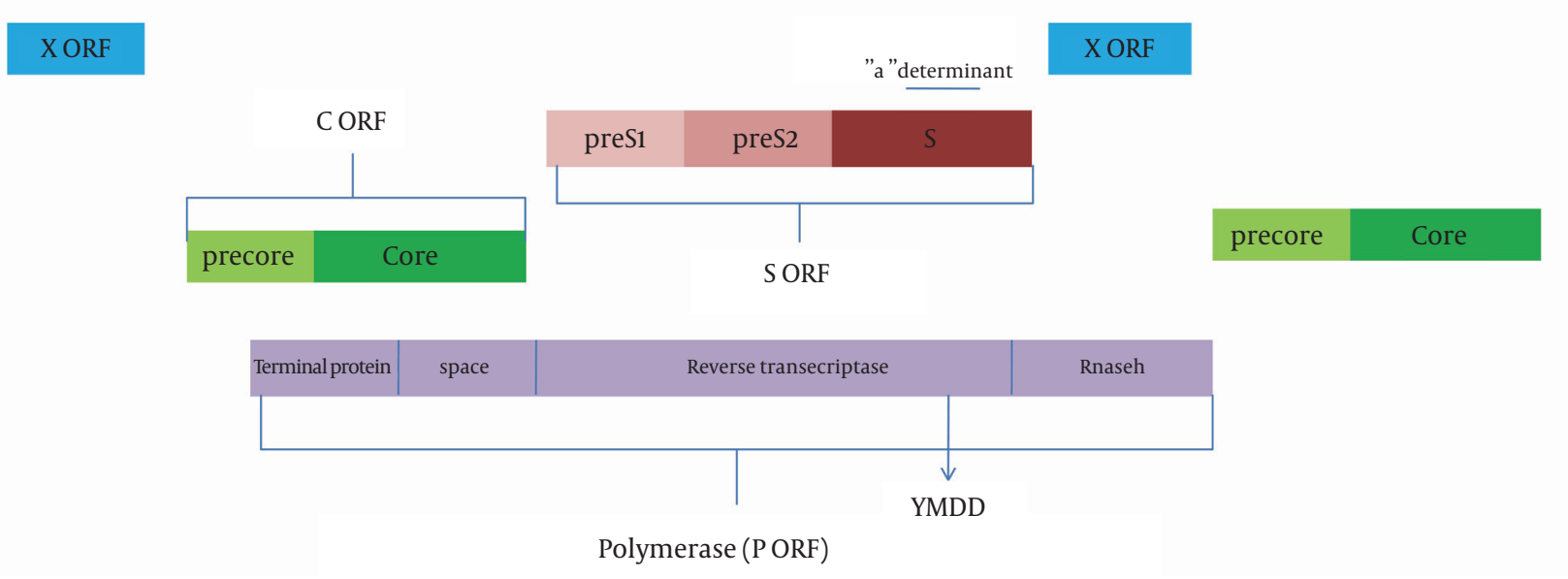

Figure 1. A schematic Figure of HBV Genome and the Four Open Reading Frames

\begin{tabular}{|c|c|c|c|c|c|}
\hline $\begin{array}{l}\text { Affected } \\
\text { Region }\end{array}$ & First Author & Year & $\begin{array}{l}\text { Journal } \\
\text { Name }\end{array}$ & Sample & Main Mutations Found to be Responsible for OHBS \\
\hline \multicolumn{6}{|c|}{ S region } \\
\hline & Hou et al. (16) & 2001 & Hepatology & OHBS patients & $\begin{array}{l}\text { G145R mutation, some positions inside and outside the } \\
\text { "a" determinant }\end{array}$ \\
\hline & Ma et al. (17) & 2012 & J Med Virol & OHBS patients & $\begin{array}{l}\text { G145R mutation, escape mutations mostly in the "a" } \\
\text { determinant }\end{array}$ \\
\hline & Liu et al. (18) & 2010 & Virol J & $\begin{array}{l}\text { OHBS in blood } \\
\text { donors }\end{array}$ & $\begin{array}{l}\text { substitutions in the regions from aa } 117 \text { to } 121 \text { and aa } 144 \\
\text { to } 147 \text {, located in the MHR and mutants with single- } \\
\text { point or multi-point G145R mutations }\end{array}$ \\
\hline
\end{tabular}


Besharat S et al.

\begin{tabular}{|c|c|c|c|c|}
\hline Yuan et al. (19) & 2010 & JHepatol & $\begin{array}{l}\text { OHBS in blood } \\
\text { donors }\end{array}$ & $\begin{array}{l}\text { substitutions in the regions from aa } 117 \text { to } 121 \text { and aa } 144 \\
\text { to } 147 \text { located in the MHR and mutants with single- } \\
\text { point or multi-point G145R mutations }\end{array}$ \\
\hline $\begin{array}{l}\text { Panigrahi et al. } \\
\text { (20) }\end{array}$ & 2010 & Virol J & $\begin{array}{l}\text { HBsAg negative } \\
\text { blood donors }\end{array}$ & $\begin{array}{l}\text { Single or multiple aa substitutions. Stop codon in } \\
\text { a case of HBV (genotype D) with a single nucleotide } \\
\text { substitution T to A at nucleotide } 207 \text { of the HBsAg and } \\
\text { in another case }\end{array}$ \\
\hline Huang et al. (21) & 2012 & JHepatol & $\begin{array}{l}\text { OHBS, HBSAg+ and } \\
\text { HBSAg-patients }\end{array}$ & MHR mutations \\
\hline $\begin{array}{l}\text { Sengupta et al. } \\
(22)\end{array}$ & 2007 & J Med Virol & $\begin{array}{l}\text { OHBS patients and } \\
\text { a group of } \mathrm{HBV} \\
\text { carriers }\end{array}$ & $\begin{array}{l}\text { mutations in Pre-S1 \& Pre-S2/S promoters/Pre-S1 coding } \\
\text { regions }\end{array}$ \\
\hline Chen et al. (23) & 2011 & Virus Res & $\begin{array}{l}\text { OHBS serum } \\
\text { samples }\end{array}$ & $\begin{array}{l}\text { Deletions covered the pre-S1 start codon and the B-cell } \\
\text { antigenic epitope in the pre-S1 protein (aa19-26). } \\
\text { Deletion (nt. 3145-52) covering nearly the entire pre-S2 } \\
\text { region }\end{array}$ \\
\hline $\begin{array}{l}\text { Pollicino et al. } \\
(24)\end{array}$ & 2007 & Hepatology & Liver tissue & $\begin{array}{l}\text { Occult HBV populations showed a large intra-individ- } \\
\text { ual genetic heterogeneity, which was comparable to } \\
\text { that observed in HBsAg-positive subjects.(Host factors), } \\
\text { detection of YMDD mutated strains in } 38 \% \text { of occult } \\
\text { HBV cases }\end{array}$ \\
\hline $\begin{array}{l}\text { Chaudhuri et } \\
\text { al. (25) }\end{array}$ & 2004 & $\begin{array}{l}\text { Gastroenter- } \\
\text { ology }\end{array}$ & $\begin{array}{l}\text { OHBS serum } \\
\text { samples }\end{array}$ & Pre-S2/S region deletion \\
\hline Bruni et al. (12) & 2011 & Virol J & $\begin{array}{l}\text { Bioinformatic ap- } \\
\text { proach }\end{array}$ & $\begin{array}{l}\text { Higher frequency of stop codons in the S ORF with no } \\
\text { significant different. Variations in seven nucleotide } \\
\text { positions. The P, the L, the M and S and the core pro- } \\
\text { teins, (but not the X), were the targets of the observed } \\
\text { significant variations. }\end{array}$ \\
\hline Ito el al. (26) & 2010 & JVirol & $\begin{array}{l}\text { OHBS serum } \\
\text { samples }\end{array}$ & $\begin{array}{l}\text { Some sporadic non common mutations are shown } \\
\text { to be relevant to OHBS; for example I110M, G119E, and } \\
\text { R169P mutations }\end{array}$ \\
\hline $\begin{array}{l}\text { Sheldon and } \\
\text { Soriano (27) }\end{array}$ & 2008 & $\begin{array}{l}\text { JAntimi- } \\
\text { crobChe- } \\
\text { mother }\end{array}$ & $\begin{array}{l}\text { OHBS serum } \\
\text { samples }\end{array}$ & Premature stop codons in the S gene \\
\hline Hass et al. (28) & 2005 & Hepatology & $\begin{array}{l}\text { OHBS serum } \\
\text { samples }\end{array}$ & $\begin{array}{l}\text { No expression of pre-S2/S mRNA due to a single G-A } \\
\text { mutation within the S gene (G458A mutation) }\end{array}$ \\
\hline \multicolumn{5}{|c|}{ X region } \\
\hline $\begin{array}{l}\text { Fukuda et al. } \\
(29)\end{array}$ & 1996 & $\begin{array}{l}\text { Microbiol } \\
\text { and Immu- } \\
\text { nol }\end{array}$ & $\begin{array}{l}\text { OHBS serum } \\
\text { samples }\end{array}$ & $\begin{array}{l}\text { An identical 8-nucleotide deletion mutation at the } \\
\text { distal part of the } \mathrm{X} \text { region affected the core promoter } \\
\text { and the enhancer II sequence }\end{array}$ \\
\hline Fujise et al. (30) & 2011 & $\begin{array}{l}\text { World J } \\
\text { Hepatol }\end{array}$ & $\begin{array}{l}\text { OHBS serum } \\
\text { samples }\end{array}$ & $\begin{array}{l}\text { Start codon in the X region, mutation of the ATG (Me- } \\
\text { thionine) start codon to GTG (Valine) }\end{array}$ \\
\hline $\begin{array}{l}\text { Pollicino et al. } \\
(24)\end{array}$ & 2007 & Hepatology & OHBS liver tissue & $\begin{array}{l}\text { A1762T/G1764A double mutation and in addition to } \\
\text { C1766T (triple mutation), point mutations in BCP }\end{array}$ \\
\hline \multicolumn{5}{|c|}{ Pregion } \\
\hline Chen et al. (31) & 2012 & Virus Res & $\begin{array}{l}\text { OHBS serum } \\
\text { samples }\end{array}$ & $\begin{array}{l}\text { Deletion located between nt. } 2067 \text { and } 2349 \text {, covered } \\
\text { the start codon of the P region }\end{array}$ \\
\hline Fang et al. (32) & 2004 & $\begin{array}{l}\text { World J Gas- } \\
\text { troenterol }\end{array}$ & $\begin{array}{l}\text { OHBS serum } \\
\text { samples }\end{array}$ & Forty point mutations \\
\hline \multicolumn{5}{|c|}{ C region } \\
\hline Chen et al. (31) & 2012 & Virus Res & $\begin{array}{l}\text { OHBS serum } \\
\text { samples }\end{array}$ & Two deletions (nt. 2001-2050 and nt. 2152-2222) \\
\hline $\begin{array}{l}\text { Garcia-Montal- } \\
\text { vo et al. (33) }\end{array}$ & 2011 & $\begin{array}{l}\text { Ann Hepa- } \\
\text { tology }\end{array}$ & $\begin{array}{l}\text { OHBS serum } \\
\text { samples }\end{array}$ & Aminoacid substitution in the core region \\
\hline $\begin{array}{l}\text { Chaudhuri et } \\
\text { al. (25) }\end{array}$ & 2004 & $\begin{array}{l}\text { Gastroenter- } \\
\text { ology }\end{array}$ & $\begin{array}{l}\text { OHBS serum } \\
\text { samples }\end{array}$ & Stop signals in precore and core regions \\
\hline $\begin{array}{l}\text { Pollicino et al. } \\
(24)\end{array}$ & 2007 & Hepatology & $\begin{array}{l}\text { OHBS serum } \\
\text { samples }\end{array}$ & G1896A and missense mutation in the core region \\
\hline
\end{tabular}

-amino acid positions between 100 and 160. The domi- $\quad$ nant epitopes of HBsAg, which are the targets of neutral- 
izing B cell responses, are located in the "a" determinant (aa 124-147) within the MHR. Mutations inducing a conformational change within the "a" determinant cause making a protein with significant changes in the antigenic epitope. These changes lead to the production of the undetectable HBsAg (21).

The most common and problematic MHR mutation, G145R, is an increasing event due to the global implication of vaccination programs and the pressure of antiviral therapy (21). Variants within the MHR of HBsAg were the point of interest in Hou et al. study in China. In 46 cases with OHBS, there were 32 amino acid substitutions found between positions 100-160 of the MHR. In addition to the G145R, 11 positions inside and five positions outside the "a" determinant were involved. Combined mutations were also detected in some patients. Another two patients had insertion mutations immediately before the "a" determinant (16).

Ma et al. in a study conducted China, 2012, found other eight escape mutations associated with OHBS, in addition to the G145 R, located mainly at positions $120,126,129,130$, $133,134,137,140,143$ and 144 with a genotypic heterogeneity (17). In the aforementioned study, a comparison was performed between OHBS patients and a group of HBV carriers, which could be considered as the strength of this work. Substitutions in the regions from aa 117 to 121 and aa 144 to 147 located in the MHR of the S gene and mutants with single-point or multi-point G145R mutations were also reported in the studies from China (18, 19). One of these studies was a phylogenetic one on blood donors and no comparisons with non-OHBS patients was performed in it (19). Other single or multiple aa substitutions have been reported to be responsible in OHBS (20). Panigrahi et al. compared the 64-160 aaof60 HBsAg (-) samples, with the reference sequences of each genotype, in their study on 729 HBsAg negative donor samples in India. They found single or multiple aa substitutions in $95 \%$ of the OHBS cases. T125M was the most common (93.3\%) aa substitution found in the MHR, mostly in subgenotype D3. Substitutions were also found at codon A128V, G71 D, L95 S, M103I, P111L, S113A, S114P, S117G, T115I, T116P, T118R, and T127A (20).

In an interesting recent study Huang et al. compared the characteristics of 61 patients with OHBS to $153 \mathrm{HB}-$ sAg (+) carriers with low titers of serum HBsAg (HBsAg-L group) and 54 samples with high serum HBsAg (HBsAg-H group). MHR mutations were seen significantly more frequently in OHBS cases (55.7\%) compared to the HBsAg-L (34.0\%) or the HBsAg-H groups (17.1\%). Thirteen representative MHR mutations were observed in patients with OHBS. Four out of the 13 mutations strongly decreased the analytical sensitivity of seven commercial HBsAg immunoassays and 10significantly impaired virion and/or S protein secretion in both $\mathrm{HuH7}$ cells and mice (36). This was a significant study regarding the comparisons.

Besides, several investigations have described mutations clustering in the aforementioned key immuno- dominant regions of the HBsAg, which are able of decreasing the immune recognition of the virus, structural alteration and various mutations in genomic regulatory regions, leading to a strong reduction of HBsAg expression $(4,5,7,22,24)$. In a functional survey by Sengupta et al. in India, the production, secretion and localization of surface proteins of HBV were studied in HepG2 cells, transfected with the wild-type and mutant pre-S1 and pre-S2/S promoters of HBV molecular clones 313.1. Their results indicated that transfected cells had reduced HBV surface protein secretion and showed cytoplasmic aggregation of HBV surface proteins. It could be concluded that OHBS may be caused due to mutations inpre-S1 and pre-S2/S promoters/pre-S1 coding region, which leads to reduced secretion of HBsAg, aggregation of HBsAg in the endoplasmic reticulum and HBsAg seronegativity (22). This was one of the few studies performed on HBV molecular clones and transfected hepatic cells, which made them capable of investigating the possible mechanisms causing OHBS, more closely.

Deletions in the pre-S1region and the resulted impaired viral packaging, has also been reported as another mechanism for OHBS. In Chen et al. (23) study, two kinds of deletions were seen covering the pre-S1 start codon and B-cell antigenic epitope in the pre-S1 protein (aa19-26), leading to a decrease in HBsAg and HBV virus particles in the serum. In another subject, a deletion was observed (nt. 3145-52), covering nearly the entire pre-S2 region. In one case, a deletion in preS2-promoter (nt. 3145-52) was identified, covering almost the whole pre-S2 region. It has been known that deletions overlapping this region could decrease the expression of the M protein, which reduces virion secretion. In this study cloning and sequencing the full-length genome of HBV wasonly done on nine healthy young Chinese patients with OHBS, who received neonatal vaccination. Although it was a powerful study due to the full-length genome sequencing, there was not any control group. Pollicino et al. investigated the lack of HBsAg production (or detection) and the inhibition of viral replication as major aspects of OHBS in their study. They studied frozen liver specimens of $17 \mathrm{HBV}$ patients (13 OHBS and four HBsAg (+) patients as a control group). Cloning and sequencing of the pre S-S genomic region was detected in only one case with small in-frame deletion and two more cases, out of 13 patients with OHBS, showed point mutation in preS2 start codon. No important mutation was found in the preS1 region of HBV clones from 16 patients. Large intra-individual genetic heterogeneity was observed in OHBS cases, comparable to the HBsAg $(+)$ subjects. Therefore, the authors concluded that the viral genomic variability does not appear to play a fundamental role in inducing the OHBS and host immune system but probably epigenetic mechanisms can play critical roles (24).

In another complete genome assessment conducted in New Delhi (2004), the major observations were: frequent quasi species variation, deletion in pre-S2/S region affect- 
ing the surface promoters (nt. 3025-54) and pre-S protein and truncated precore and core regions, related to the stop signal (25). In these two studies, a whole genome sequencing was done in patients with OHBS, although the first one (Pollicino study) could be considered more valuable due to having a control group of HBSAg (+) samples and also working on the liver tissues.

It seems that mutations introducing stop codons in the $S$ ORF are among the common frequent mutations, not necessarily resulting in OHBS. As Bruni et al. in a bioinformatics approach, showed that although the frequency of stop codons in the S ORF was higher in OHBS than nonOHBS sequences, the difference was not statistically significant. The authors also found that variations in seven nucleotide positions were significantly associated with OHBS. The P, the L, the M and S and the core proteins, but not the $\mathrm{X}$, were the targets of the observed significant variations (12).

Panigrahi et al. found a stop codon in one sample of HBV/D, with a single T to A nucleotide substitution at nucleotide 207 of the HBsAg (20). Some sporadic non common mutations are shown to be relevant to OHBS ,for example: I110M, G119E and R169P mutations which could impair virion secretion (26).

Drug resistance is one of the most problematic issues, mostly resulting from mutations in the $S$ region. A triple mutational pattern (rtV173L + rtL180M + rtM204V) causing lamivudine resistance has recently been shown to enhance HBV replication. Other lamivudine-associated resistance mutations may cause premature stop codons in the $S$ gene, also resulting in impaired secretion of the $\operatorname{HBsAg}(31)$.

Finally, some mutations affect post-translational production of HBV proteins, inducing OHBS in some cases, as shown in Hass et al. case report. Genomes from two patients showed a low replication phenotype at the level of RNA encapsidation or HBV DNA synthesis, not attributable to uncommon mutations in the terminal protein domain of P protein. A single G-A mutation was identified within the $S$ gene (G458A mutation), responsible for this effect. The nuclear run-on transcription showed that the G458Amutation acts at the post-transcriptional level(28).

\subsection{Mutations in the $X$ Region of HBV and Occult HBV Status}

$\mathrm{X}$ ORF produces the $\mathrm{X}$ protein $(\mathrm{HBx})$ and although the exact function of HBx during HBV replication is still unclear, multiple studies suggest that $\mathrm{HBx}$ is necessary for viral replication in vivo and in vitro (30, 37-40). Mutations in the $\mathrm{X}$ region can involve the regulatory elements that control replication, like the basal core promoter and the enhancer II. Because the basal core promoter overlaps with the $\mathrm{X}$ gene in the concomitant reading frame, the A1762T plus G1764A core promoter mutations also cause changes in the X gene at XK130M and XV131I (30, 37-40).

Deletion mutations in $\mathrm{X}$ region are found in OHBS pa- tients. Fukuda et al. in a very early study on $\mathrm{X}$ gene mutation in Japan, showed an identical 8-nucleotide deletion mutation at the distal part of the $\mathrm{X}$ region in a major group of these patients (85.7\%). This mutation affected the core promoter and the enhancer II sequence of HBV DNA and created a translational stop codon which truncated the $\mathrm{X}$ protein by 20 amino acids from the C-terminal end. All the HBV DNAs had a precore mutation at the 83rd nucleotide, resulting in disruption of HBeAg synthesis (29). In this study, serum HBV DNA from patients with non-B non-C hepatitis (NBNC) was sequenced and compared to that of the patients with alcoholic liver disease and autoimmune hepatitis. Therefore, these results could be very interesting keeping the studied group in mind.

The start codon in the $\mathrm{X}$ region could also be mutated and cause OHBS. In a Japanese study, the ATG (methionine) start codon had mutated to GTG (valine) and resulted in OHBS in one case (30). Fujise sequenced the full genome of $\mathrm{HBV}$ in this seronegative case of OHBS, which is worth giving more attention. Nucleotide exchange of A1762T and G1764A is another important mutation, which has been suggested to be responsible in OHBS. This was reported in Pollicino's study on a group of 13 OHBS and four cases of overt HBV (the control group). They reported the double mutation of A1762T and G1764A in 4 OHBS cases and three controls. Triple mutation of these two plus C1766T was only observed in two OHBS cases. Point mutations (from 1 to 4 ) in BCP were also reported in the mentioned groups (24). The results of Pollicino's study are valuable regarding the comparison they made between OHBS cases and overt patients with HBV from the point of potential mutations assumed to be responsible in OHBS.

\subsection{Mutations in P Region and Occult HBV Status}

One of the regions with mutation susceptibility in HBV ORF is P region, which encodes the polymerase protein (reverse transcriptase) or the POL. The HBV genome is organized in a way that the envelope $(S)$ gene is completely over-lapped by the polymerase gene, so it is logical to assume that changes in virus encoding, associated with antiviral resistance in the polymerase, may have consequent changes on the envelope gene (27), showing a close relationship between mutations in $S$ and $P$ regions of HBV genome.

This region is also susceptible to deletion mutations and having a key role in HCC progression. In a full-length genome study of HBV DNA in China, 14 out of the 16 clones, constructed from 3 cases of genotype B showed deletions in the P region. These deletions were located between nt. 2067 and 2349, covering the start codon of the P region, which is believed to reduce the enzymatic activity of the wild-type protein and may be accounted for low viral loads in OHBS (31). Forty point mutations in polymerase gene were found, resulting in changes in 11 amino acids in one case of OHBS, in a study by Fang et al. conducted in 
a high endemic area for HCC, in China in2004 (32). Therefore mutations in this region should draw the attention to the importance of related drug resistance and hepato carcinogenesis.

\subsection{Mutations in C Region and Occult HBV Status}

C ORF of HBV genome encodes core protein and HBeAg (8-10). The core shell of hepatitis B virus is a potent immune stimulator, stimulating a strong neutralizing immune response to foreign epitopes $(39,40)$. Mutations in this region of $\mathrm{HBV}$ genome have not been assumed to be responsible for OHBS, as frequently as other regions spoken above, therefore there are not as many studies done on the subject. In one study in China BCP deletion mutation was investigated in three clones from one case ( $\mathrm{nt}$ 1754 , nt.1751, and nt. 1754). The deletions in the BCP region covered more than one TA box. In the $C$ region, deletions were observed in 4 subjects. Among 14 strains with deletions in the $C$ region, 11 had deletions in all parts of both the $\mathrm{C}$ and $\mathrm{P}$ regions, all in cases with genotype $\mathrm{B}$. In one case, two deletions (nt. 2001-2050 and nt. 2152-2222) covered $22 \%$ of the $C$ region (31).

In another study Garcia-Montalvo et al. reported 24 (6.4\%) cases with OHB Samong 372 Mexican blood donors. Phylogenetic analysis in this subgroup showed aa substitution in the core region of nine samples, mostly located in immune dominant epitopes. There was no precore stop codon mutants in these patients (33). Truncated precore and core mutations, resulting in stop signals were found in another study in India on patients diagnosed as OHBS, who were not on anti-viral treatment (25). All mentioned studies were observational surveys on a group of patients with OHBS, looking for mutations in the specific region of HBV genome.

On the other hand, Pollicino et al. in a whole genome study on OHBS and overt HBV cases reported G1896A nucleotide mutation, resulting in a stop signal at codon 28 , within the precore region, which prevents the HBeAg synthesis in eight out of 13 OHBS cases and in all 4 overt HB$\mathrm{sAg}(+)$ cases (control group). Missense mutations within different core antigen immunogenic epitopes were also observed in HBV isolates, in both patients with OHBS and the control group with overt HBV infection (24).

\section{Conclusions}

OHBS is a complex clinical entity documented worldwide. HBV sequences from these individuals demonstrate numerous mutations/deletions and alterations that can result in decreased immune recognition of the virus, impaired HBV packaging and decreased HBsAg expression. Moreover, mutations affecting post-translational protein production and treatment-associated mutations are observed in these patients. However, the aforementioned studies mostly lacked a control group. In addition, whole-length HBV sequencing data, resulting in direct comparison of mutations between the genome sequences of occult and non-occult strains, even though scant, have conflicting results suggesting that OHBS is often a result of multiple mechanisms. Additional studies on full-length HBV genomes from occult and non-occult HBV cases may shed more light on the interplay between different mechanisms involved in the pathogenesis of OHBS. Such insights are of utmost importance to develop new therapeutic strategies.

\section{Acknowledgements}

Authors tend to appreciate kind support and expertise guidance of Dr. Hossein Poustchi and Dr. Ashraf Mohamadkhani (DDRI).

\section{Authors' Contribution}

Sima Besharat and Aezam Katoonizadeh contributed in study concept, design and drafting the manuscript and Abdolvahab Moradi contributed in critical revision of the manuscript for important intellectual content and study supervision.

\section{Financial Disclosure}

No financial support was taken for this review.

\section{Funding/Support}

Authors received no financial support or grant for this review.

\section{References}

1. Ocana S, Casas ML, Buhigas I, Lledo JL. Diagnostic strategy for occult hepatitis B virus infection. World $J$ Gastroenterol. 2011;17(12):1553-7.

2. de la Fuente RA, Gutierrez ML, Garcia-Samaniego J, Fernandez-Rodriguez C, Lledo JL, Castellano G. Pathogenesis of occult chronic hepatitis B virus infection. World J Gastroenterol. 2011;17(12):15438.

3. Han YF, Zhao J, Ma LY, Yin JH, Chang WJ, Zhang HW, et al. Factors predicting occurrence and prognosis of hepatitis-B-virus-related hepatocellular carcinoma. World J Gastroenterol. 2011;17(38):425870.

4. Raimondo G, Allain JP, Brunetto MR, Buendia MA, Chen DS, Colombo M, et al. Statements from the Taormina expert meeting on occult hepatitis B virus infection. J Hepatol. 2008;49(4):652-7.

5. Dandri M, Locarnini S. New insight in the pathobiology of hepatitis B virus infection. Gut. 2012;61 Suppl 1:i6-17.

6. Said ZN. An overview of occult hepatitis B virus infection. World J Gastroenterol. 2011;17(15):1927-38.

7. Raimondo G, Pollicino T, Cacciola I, Squadrito G. Occult hepatitis B virus infection. J Hepatol. 2007;46(1):160-70.

8. Dienstag JL. Hepatitis B virus infection. $N$ Engl J Med 2008;359(14):1486-500.

9. Nguyen DH, Ludgate L, Hu J. Hepatitis B virus-cell interactions and pathogenesis. J Cell Physiol. 2008;216(2):289-94.

10. Chang JJ, Lewin SR. Immunopathogenesis of hepatitis B virus infection. Immunol Cell Biol. 2007;85(1):16-23.

11. Martin CM, Welge JA, Shire NJ, Rouster SD, Shata MT, Sherman $\mathrm{KE}$, et al. Genomic variability associated with the presence of occult hepatitis B virus in HIV co-infected individuals. J Viral Hepat. 2010;17(8):588-97.

12. Bruni R, Prosperi M, Marcantonio C, Amadori A, Villano U, Tritarelli $\mathrm{E}$, et al. A computational approach to identify point muta- 
tions associated with occult hepatitis B: significant mutations affect coding regions but not regulative elements of HBV. Virol J. 2011;8:394.

13. Mohammadkhani A, Montazeri G, Poustchi H. The Importance of Hepatitis B Virus Genome Diversity in Basal Core Promoter Region. Middle East J Dig Dis. 2011;3(1):13-9.

14. Kramvis A, Kew M, Francois G. Hepatitis B virus genotypes. Vaccine. 2005;23(19):2409-23.

15. Raimondo G, Caccamo G, Filomia R, Pollicino T. Occult HBV infection. Semin Immunopathol. 2013;35(1):39-52.

16. Hou J, Wang Z, Cheng J, Lin Y, Lau GK, Sun J, et al. Prevalence of naturally occurring surface gene variants of hepatitis B virus in nonimmunized surface antigen-negative Chinese carriers. Hepatology. 2001;34(5):1027-34.

17. Ma Q, Wang Y. Comprehensive analysis of the prevalence of hepatitis $B$ virus escape mutations in the major hydrophilic region of surface antigen. J Med Virol. 2012;84(2):198-206.

18. Liu Y, Li P, Li C, Zhou J, Wu C, Zhou YH. Detection of hepatitis B virus DNA among accepted blood donors in Nanjing, China. Virol J. 2010;7:193.

19. Yuan Q, Ou SH, Chen CR, Ge SX, Pei B, Chen QR, et al. Molecular characteristics of occult hepatitis B virus from blood donors in southeast China. J Clin Microbiol. 2010;48(2):357-62.

20. Panigrahi R, Biswas A, Datta S, Banerjee A, Chandra PK, Mahapatra PK, et al. Anti-hepatitis B core antigen testing with detection and characterization of occult hepatitis B virus by an in-house nucleic acid testing among blood donors in Behrampur, Ganjam, Orissa in southeastern India: implications for transfusion. Virol J. 2010;7:204.

21. Huang C-H, Yuan Q, Chen P-J, Zhang Y-L, Chen C-R, Zheng Q-B, et al. Influence of mutations in hepatitis $B$ virus surface protein on viral antigenicity and phenotype in occult HBV strains from blood donors. J Hepatol. 2012;57(4):720-9.

22. Sengupta S, Rehman S, Durgapal H, Acharya SK, Panda SK. Role of surface promoter mutations in hepatitis B surface antigen production and secretion in occult hepatitis B virus infection. J Med Virol.2007;79(3):220-8.

23. Chen CJ, Yang HI. Natural history of chronic hepatitis B REVEALed.J Gastroenterol Hepatol. 2011;26(4):628-38.

24. Pollicino T, Raffa G, Costantino L, Lisa A, Campello C, Squadrito $\mathrm{G}$, et al. Molecular and functional analysis of occult hepatitis B virus isolates from patients with hepatocellular carcinoma. Hepatology. 2007; 45(2):277-85.

25. Chaudhuri V, Tayal R, Nayak B, Acharya SK, Panda SK. Occult hepatitis B virus infection in chronic liver disease: full-length genome and analysis of mutant surface promoter. Gastroenterology. 2004;127(5):1356-71.

26. Ito K, Qin Y, Guarnieri M, Garcia T, Kwei K, Mizokami M, et al. Im- pairment of hepatitis B virus virion secretion by single-aminoacid substitutions in the small envelope protein and rescue by a novel glycosylation site. J Virol. 2010;84(24):12850-61.

27. Sheldon J, Soriano V. Hepatitis B virus escape mutants induced by antiviral therapy. J Antimicrob Chemother. 2008;61(4):766-8.

28. Hass M, Hannoun C, Kalinina T, Sommer G, Manegold C, Gunther S. Functional analysis of hepatitis $B$ virus reactivating in hepatitis B surface antigen-negative individuals. Hepatology. 2005;42(1):93-103.

29. Fukuda R, Ishimura N, Kushiyama Y, Moriyama N, Ishihara S, Chowdhury A, et al. Hepatitis B virus with $\mathrm{X}$ gene mutation is associated with the majority of serologically "silent" non-b, non-c chronic hepatitis. Microbiol Immunol.1996;40(7):481-8.

30. Fujise K, Tatsuzawa K, Kono M, Hoshina S, Tsubota A, Niiya M, et al. A mutation of the start codon in the $\mathrm{X}$ region of hepatitis $\mathrm{B}$ virus DNA in a patient with non-B, non-C chronic hepatitis. World J Hepatol. 2011;3(2):56-60.

31. Chen SI, Zhao YX, Fang Y, Xu WZ, Ma YX, Song ZW, et al. Viral deletions among healthy young Chinese adults with occult hepatitis B virus infection. Virus Res. 2012;163(1):197-201.

32. Fang ZL, Zhuang H, Wang XY, Ge XM, Harrison TJ. Hepatitis B virus genotypes, phylogeny and occult infection in a region with a high incidence of hepatocellular carcinoma in China. World $J$ Gastroenterol. 2004;10(22):3264-8.

33. Garcia-Montalvo BM, Ventura-Zapata LP. Molecular and serological characterization of occult hepatitis B infection in blood donors from Mexico. Ann Hepatol. 2011;10(2):133-41.

34. Chotiyaputta W, Lok AS. Hepatitis B virus variants. Nat Rev Gastroenterol Hepatol. 2009;6(8):453-62.

35. Hsu CW, Yeh CT. Emergence of hepatitis B virus $S$ gene mutants in patients experiencing hepatitis B surface antigen seroconversion after peginterferon therapy. Hepatology. 2011;54(1):101-8.

36. Tang H, Oishi N, Kaneko S, Murakami S. Molecular functions and biological roles of hepatitis B virus $\mathrm{x}$ protein. Cancer Sci. 2006;97(10):977-83.

37. Wei Y, Neuveut C, Tiollais P, Buendia MA. Molecular biology of the hepatitis $\mathrm{B}$ virus and role of the $\mathrm{X}$ gene. Pathol Biol (Paris). 2010;58(4):267-72.

38. Seeger C, Mason WS. Hepatitis B virus biology. Microbiol Mol Biol Rev. 2000;64(1):51-68.

39. Murakami S. Hepatitis B virus X protein: a multifunctional viral regulator. J Gastroenterol. 2001;36(10):651-60.

40. Roseman AM, Borschukova O, Berriman JA, Wynne SA, Pumpens P, Crowther RA. Structures of hepatitis B virus cores presenting a model epitope and their complexes with antibodies. J Mol Biol. 2012;423(1):63-78. 